\title{
Assessing the effects of precipitation and temperature changes on hydrological processes in a glacier-dominated catchment
}

\author{
Xiaolei Wang, ${ }^{1}$ Yi Luo, ${ }^{1,2} *$ Lin Sun $^{1}$ and Yiqing Zhang ${ }^{1}$ \\ ${ }^{1}$ Key Lab of Ecosystem Network Observation and Modeling, Institute of Geographic Sciences and Natural Resources Research, Chinese Academy of \\ Sciences (CAS), University of CAS, Beijing 100101, China \\ ${ }^{2}$ Xinjiang Institute of Ecology and Geography, CAS, Urumqi, Xinjiang, 830011, China
}

\begin{abstract}
:
The processes by which climate change affects streamflow in alpine river basins are not entirely understood. This study evaluated the impacts of temperature and precipitation changes on runoff and streamflow using glacier-enhanced Soil and Water Assessment Tool model. The study used observed and detrended historical meteorological data for recent decades (1961-2005) to analyse individual and combined effects of temperature and precipitation changes on snow and glacier melts and discharges in the Sary-Djaz-Kumaric River Basin (SRB), Tianshan Mountains. The results showed a 1.3\% increase in annual snowmelt in the basin, mainly because of an increase in precipitation. Snowmelt in the basin varied seasonally, increasing from April through May because of increasing precipitation and decreasing from July through September because of rising temperature. Glacier melt increased by $5.4 \%, 5.0 \%$ of which was due to rising temperature and only $0.4 \%$ due to increasing precipitation. Annual streamflow increased by $4.4 \%$, of which temperature and precipitation increases accounted for $2.5 \%$ and $1.9 \%$, respectively. The impacts of temperature and precipitation changes on streamflow were especially significant after 1980 and even more so in September. Glacier melt, due to temperature rise, was the dominant driver of increasing streamflow in the glacier-dominated SRB, Tianshan Mountains. Copyright (C) 2015 John Wiley \& Sons, Ltd.
\end{abstract}

KEY WORDS climate change; snow melt; glacier melt; streamflow; SWAT; detrended method

Received 6 March 2015; Accepted 5 May 2015

\section{INTRODUCTION}

Climate change is gradually becoming the single most important environmental problem in the 21 st century (Campbell et al., 2011). Global mean air temperature is increasing, and the volume, intensity, frequency and form (e.g. rain or snow) of precipitation are changing throughout the climatic regions of the world (Solomon, 2007). In addition, the emission of greenhouse gases will cause further warming and changes to numerous climate components (IPCC, 2013). The variations in temperature and precipitation could severely affect the hydrology and water resources of major river basins in the world, including the quantity and seasonal distribution of streamflow (Campbell et al., 2011; Kure et al., 2013). Moreover, the hydrology of mountainous, snow-fed and glacier-fed river basins is noticeably more sensitive to climate variability as snow and ice respond rapidly to

\footnotetext{
*Correspondence to: Yi Luo, Institute of Geographic Sciences and Natural Resources Research, Chinese Academy of Sciences (CAS), University of CAS, Beijing 100101, China.

E-mail: luoyi@igsnrr.ac.cn
}

even slight variations in precipitation and temperature (Carrivick and Brewer, 2004; López-Moreno and García-Ruiz, 2004).

In highly glacierized catchments, the contribution of melt water to annual discharge is larger than that of rain (Jost et al., 2012). In addition, summer streamflow, which is needed for irrigation, is maintained by the presence of glaciers in such catchments (Dahlke et al., 2012). It is observed that even in basins with glacier fractions less than 5\%, melt water can significantly contribute to summer runoff (Hagg et al., 2007). The impact of climate change on glacier input to streamflow has been the focus of significant research in the last few decades (Unger-Shayesteh et al., 2013).

Scientific reports show that since the end of the Little Ice Age, glaciers in the Tianshan Mountains have been retreating (e.g. Liu and Han, 1991; Solomina et al., 2004; Guo et al., 2015; Liu et al., 2015). This retreat has accelerated since the second half of the last century because of warming climate (Sorg et al., 2012). Glacier retreat would bring about runoff changes. Studies suggest that runoff changes in glacier and snow-dominated catchments should be further investigated in the context of climate change. 
Statistical techniques have been widely used to study the response of streamflow to precipitation and temperature changes, not only in Tianshan Mountains (Li et al., 2010b; Wang et al., 2013; Chen and Chen, 2014) but also in other areas around the world (Khaliq et al., 2009; Nalley et al., 2012). However, the application of statistical techniques in runoff analysis is limited by intra-annual and inter-annual regulations of streamflow by glaciers. Although statistical techniques are simple, easy to use and available for analysing monotonic and shift trends, the application methods have a number of limitations (Unger-Shayesteh et al., 2013), such as lacking point significance assessment and based on specific distribution assumptions that are usually invalid for hydro-meteorological data series. Thus, such techniques could overestimate or underestimate the effects of climate change on streamflow and thereby fail to correctly explain and interpret the processes (Chen et al., 2006; Fan et al., 2011). Furthermore, statistical techniques hardly quantify the relative impacts of changes in temperature and precipitation on snowmelt, glacier melt and streamflow.

Hydrological models can be used to determine the relative impacts of precipitation and temperature variations on watershed hydrology, including glaciers and snow packs. Distributed hydrological models with high spatiotemporal resolutions (often used to study changes in runoff components) are now widely updated with modules for simulating glacier and snow hydrological processes in watersheds (Immerzeel et al., 2012; Luo et al., 2013; Lutz et al., 2014). These models use glacier mass balance and dynamics to simulate glacier hydrological processes at basin scale. The mass balance can be related to the area of change using volume-area scaling relationship. This allows for simulations of change in glacial area and the related impacts on glacier hydrology. There is significant research on glacier-dominated watershed hydrology (Sorg et al., 2012; Unger-Shayesteh et al., 2013), most of which addresses long-term changes in future climate scenarios (Miller et al., 2012; Hagg et al., 2013; Immerzeel et al., 2013; Lutz et al., 2014; Pellicciotti et al., 2014; Radic and Hock, 2014). Although future climate change is likely to result in significant changes in hydrological regimes (Parry, 2007), projections based on global and/or regional climate models are marred by considerable uncertainties (Karlsson et al., 2014). Furthermore, future discharge, glacier area and mass balance lack validation because of lack of future data. To better understand projected effects of future climate change on runoff, there is a need to quantitatively analyse the impacts of precipitation and temperature changes on streamflow based on historical observations.

The main objective of this study was to analyse the effects of precipitation and temperature changes in recent decades on glacier melt, snow melt and streamflow using a distributed hydrological model in a glacier-dominated headwater catchment in Tianshan Mountains. Quantitative conclusions drawn from the study could deepen current understanding of hydrological response of glacier/snow-dominated catchments to climate change. It will lay the basis not only for future hydrological studies in Tianshan Mountain catchments but also for other glacier/snow-dominated catchments across the globe.

\section{MATERIALS AND METHODS}

\section{Study area}

This study was conducted in the headwater region of Sary-Djaz-Kumaric River Basin (SRB). The Sary-DjazKumaric River originates from the northwestern slopes of Khan Tengri in the central region west of Tianshan Mountains. It flows through Kyrgyzstan and Kazakhstan before reaching China. Most of the catchment area is in Kyrgyzstan. While the river is known as Sary-Djaz in Kyrgyzstan, it is called Kumaric River in China, and it is called Aksu River after joining Toshkan River. The total length of Sary-Djaz-Kumaric River is $306 \mathrm{~km}$. It is the largest tributary of Aksu River and is a major source of inflow to Tarim River. The area of the catchment above Xiehela Hydrological Station (XHS) is $12977 \mathrm{~km}^{2}$. The altitude range of the SRB is $2000-7435 \mathrm{~m}$ above sea level (a.s.l.), with an average elevation of $3745 \mathrm{ma}$ a.s.l. and highest peak (Tumur) of 7435 ma.s.l. (Figure 1).

The SRB has a typical continental climate, with an average annual temperature range of approximately -1 to $-8^{\circ} \mathrm{C}$. The temperature trend for the 1950 s to 2000 s is significantly positive (Kundzewicz et al., 2015). The seasonal distribution of precipitation is highly uneven, with $55-66 \%$ concentrated in the summer months of June to August. The average annual rainfall in the $2650-3500 \mathrm{~m}$ a. s.l. altitude zone is $300-400 \mathrm{~mm}$ and is as high as $700 \mathrm{~mm}$ in the $4000-5000 \mathrm{~m}$ a.s.l. altitude zone. There is no significant trend in the local precipitation (Aizen et al., 1997; Bolch, 2007).

Approximately one fifth of SRB is covered by glaciers, with glaciers mainly occurring in the $3000-6500 \mathrm{~m}$ a.s.l. altitude range. A plot of SRB area versus altitude follows a near-normal distribution curve (Figure 2). Glacier retreat and mass loss in recent decades have significantly accelerated in the Tianshan Mountains (Narama et al., 2010; Wang et al., 2010; Sorg et al., 2012), but at a relatively slow rate in the SRB. Only a small change in glacier area $(-1.3 \%)$ was observed at China's Tumur Peak in 1965-2000 (Shangguan et al., 2009). A slightly higher rate $(-3.7 \pm 2.7 \%)$ was reported for the Kyrgyzstan portion of Aksu Basin in 1990-2010 (Osmonov et al., 2013). 


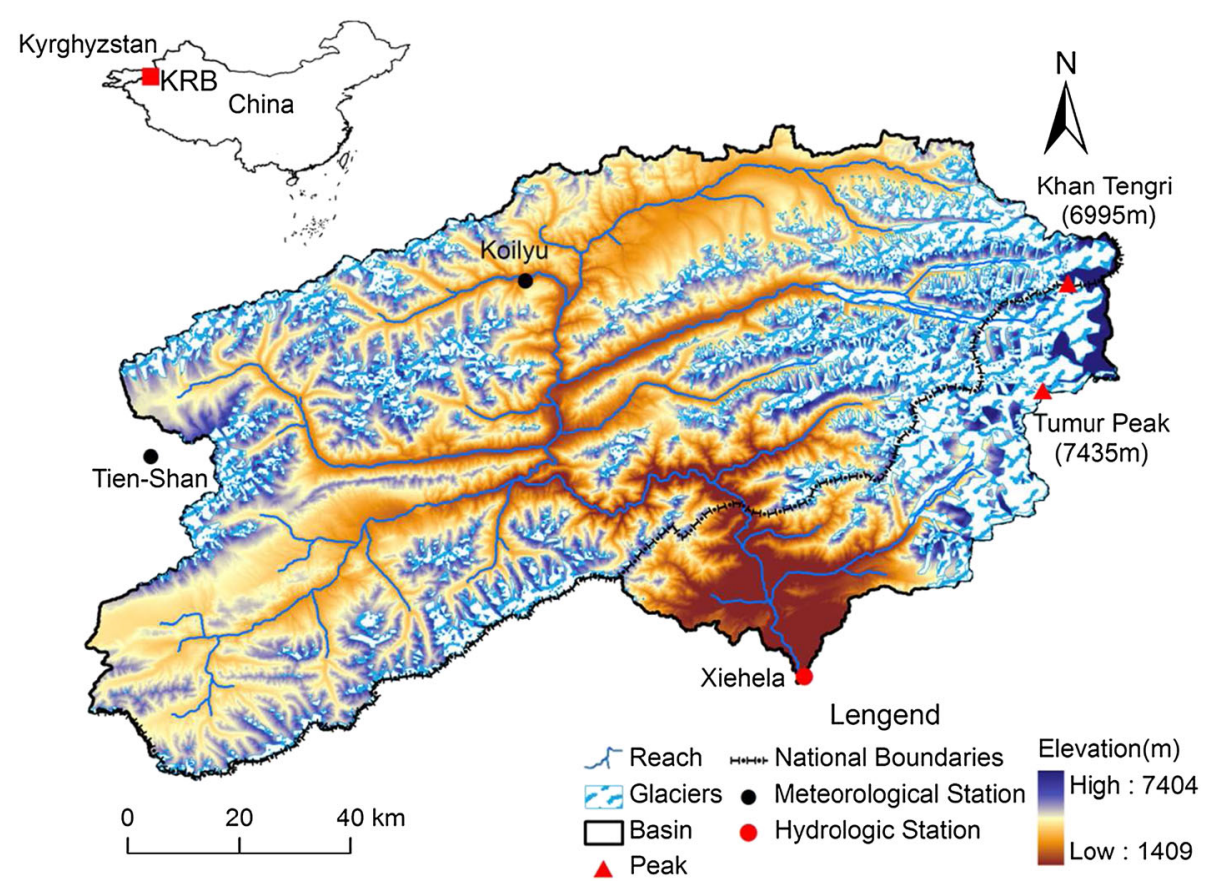

Figure 1. A map depicting the location of the Sary-Djaz-Kumaric River Basin along with the glaciers, metrological and hydrological stations, and the ambient topography

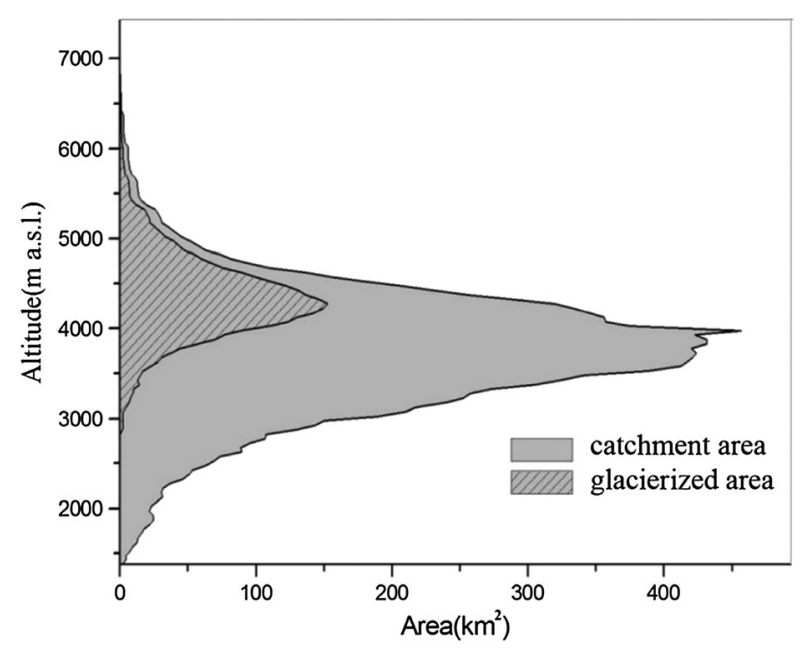

Figure 2. Plot of catchment area (shaded grey) and glacier area (shaded grey with stripes) in relation to altitude in the Sary-Djaz-Kumaric River Basin

\section{Glacier-enhanced SWAT model}

The Soil and Water Assessment Tool (SWAT) (Arnold et al., 1998) is a physically based, spatially distributed model used for simulating basin-scale hydrological processes. SWAT is available in the public domain along with the source code and can be adapted for specific simulation scenarios. SWAT is applied in various climatic, soil, land use and management conditions across the globe (Gassman et al., 2007; Arnold et al., 2012).
Although SWAT can simulate precipitation-runoff processes and snow hydrology, the official version does not include glacio-hydrological processes. For application in the alpine river catchments in the Tianshan Mountains, Luo et al. (2013) developed a glacier-hydrology module of SWAT that simulates glacier mass balance and dynamics, called the glacier-enhanced SWAT model hereafter.

Hydrological response unit (HRU) is the basic unit at which land surface hydrological processes are simulated in SWAT (Arnold et al., 2012). In the adapted SWAT, all the glaciers in a subbasin are treated as single glacier HRU (GHRU), which is the basic unit for simulating glacier hydrological processes (Luo et al., 2013). Simulated glacier mass balance components in GHRU include mass accumulation, sublimation, ice melt, snowmelt and melt water freeze. To account for variations in glacier area, precipitation and temperature along elevation, each GHRU is divided into elevation bands, and glacier mass balance is simulated on this basis. Glacier volume is derived from total glacier mass balance via ice density as follows:

$$
V_{\mathrm{gla}}=\frac{W}{\rho_{\mathrm{g}}}
$$

where $W$ is the total mass of glacier $(\mathrm{kg})$ and $\rho_{\mathrm{g}}$ is the density of ice $\left(\mathrm{kg} / \mathrm{m}^{3}\right)$ generally taken as $0.97 \mathrm{~kg} / \mathrm{m}^{3}$.

Glacier area is updated via a volume-area scaling relation. The volume-area scaling relation was introduced by Chen and Ohmura (1990) and has since been widely used in glacial/hydrological models (Stahl et al., 2008; Hirabayashi et al., 2010; Jost et al., 2012; Marzeion et al., 
2012; Lutz et al., 2013; Bliss et al., 2014; Marzeion et al., 2014; Wortmann et al., 2014; Bahr et al., 2015).

$$
A_{\mathrm{gla}}=\left(\frac{V_{\mathrm{gla}}}{m}\right)^{1 / n}
$$

where $A_{\text {gla }}\left(\mathrm{km}^{2}\right)$ and $V_{\text {gla }}\left(\mathrm{m} \mathrm{km}^{2}\right)$ are surface area and volume of glacier, respectively. The constants $m$ and $n$ are derived from glacier measurements (Chen and Ohmura, 1990). Following Liu et al. (2003), $m$ is set at 40 and $n$ at 1.35 in this study in which values were derived from measured glacier data in northwest China. In this study, glaciers in the same subbasin were lumped into single GHRU. Because of difficulties in dealing with large numbers of small-area glaciers, glacio-hydrological models combine such glaciers into a single unit at a subcatchment scale (Wortmann et al., 2014) or at a gridcell scale (Stahl et al., 2008; Jost et al., 2012; Lutz et al., 2013). Irrespective of the glacier combination method used, uncertainties could arise in estimating glacier area from nonlinear volume-area scaling relation, which pertains to single glaciers.

In this model, runoff in each hydrologic response unit (HRU or GHRU) was from three sources - rainfall, snowmelt and glacier melt. Glacier melt included supraglacial snowmelt and ice melt. All glacier melt and portions of rainfall and snowmelt flow on the land surface went directly to channel systems, while other portions infiltrated into the soil. Part of the infiltrated water occurred as lateral flow or aquifer recharge. Released baseflow from aquifer storage contributed to streamflow. Surface runoff, lateral flow and baseflow were routed through tributary channels to each subbasin outlet and eventually to the basin outlet via main channels. Also, channel water loss was removed from routed river discharge.

\section{Model setup}

SWAT requires spatial data (e.g. topography, land use/ cover, soil type and glacier inventory), forcing data (e.g. daily precipitation and temperature) and streamflow data.

Subbasin and HRU delineation. The flow domain and flow paths in the study area were derived from ASTER Digital Elevation Model using the ArcSWAT interface in SWAT2005 package. Using the aforementioned data and interface, the flow domain was delineated into a total of 69 subbasins.

The 2009 land use/cover map from the European Aviation Safety Agency, with raster grid resolution of $300 \mathrm{~m} \times 300 \mathrm{~m}$, was used in the SWAT model. The glacier map was derived from the updated version of Randolph Glacier Inventory (RGI) (Arendt et al., 2012). The RGI layer was overlaid on the land use/cover map, and then the portions of bare land $(63 \%)$, range grassland (13\%), agricultural land $(2 \%)$ and glacier (22\%) in the study area delineated.
A total of 1536 glaciers (with total area of $2881 \mathrm{~km}^{2}$ ) were identified in the study area (Table I). Although glaciers with area exceeding $5 \mathrm{~km}^{2}$ accounted for only $5 \%$ of the total number of glaciers, this group of glaciers accounted for $\sim 72 \%$ of total glacier area in the basin. Then glaciers with area less than $1 \mathrm{~km}^{2}$ accounted for $80 \%$ of the total number of glaciers but accounted for only $12 \%$ of the total glacier area. The largest glacier in the basin was $555 \mathrm{~km}^{2}$ in area. Among the 69 delineated subbasins, 12 were without glaciers. The range of glacier-to-basin area ratio for the 57 glacierized subbasins was $0.05-83 \%$. All the glaciers in each subbasin (big and small) were lumped into a single GHRU, resulting into a total 57 GHRUs for the glacierized subbasins. The GHRUs were next divided into ten elevation bands of equal ranges, and glacier mass simulated based on the bands. The total mass balance was the aggregate of the mass balances of the bands of each GHRU. The glacier area was then updated through the volume-area scaling relation. It was assumed that glaciers in the lowest elevation bands either advanced or retreated (Zhang et al., 2012).

HRUs for the non-glacierized portions of the subbasins were derived by combing and lumping similar land use/cover and soil types (Neitsch et al., 2011). The Harmonized World Soil Database of the Food and Agriculture Organization of the United Nations was used to derive the soil properties, including soil texture and soil type. The soils were re-grouped on the basis of grain size distribution following the US Soil Classification System. The main soils included alpine meadow soil $(21 \%)$, subalpine meadow soil (2\%), rock outcrop (73\%), mountain chestnut soil (2\%) and light brown calcic soil (1\%). The delineation and grouping processes above resulted in 324 HRUs in the SRB study area.

Climate input. Data compiled by the Asian Precipitation Highly-Resolved Observational Data Integration Towards Evaluation of Water Resources (APHRODITE) program were used for climate input. APHRODITE is a long-term, continental-scale daily precipitation and mean air temperature product based on a dense network of rain gauge and thermometric data, with a spatial resolution of $0.25^{\circ}$. Its databases, APHRO-MA V1101 (Yatagai et al.,

Table I. Glacier characteristics in the headwater catchment of the Sary-Djaz-Kumaric River Basin from Randolph Glacier Inventory

\begin{tabular}{lcccc}
\hline $\begin{array}{l}\text { Glacier } \\
\text { area }\left(\mathrm{km}^{2}\right)\end{array}$ & $\begin{array}{c}\text { Glacier } \\
\text { count }(-)\end{array}$ & Percentage & $\begin{array}{c}\text { Total } \\
\text { area }\left(\mathrm{km}^{2}\right)\end{array}$ & Percentage \\
\hline$<0.5$ & 994 & 65 & 184 & 6 \\
$0.5-1$ & 235 & 15 & 168 & 6 \\
$1-2$ & 157 & 10 & 217 & 8 \\
$2-5$ & 80 & 5 & 246 & 9 \\
$>5$ & 70 & 5 & 2066 & 72 \\
\hline
\end{tabular}


2012) and Aphro_TAVE_MA_V1204R1 (Yasutomi et al., 2011), provide data appropriate for SWAT model simulation. The APHRODITE data were corrected with observation data before use in SWAT.

The observation data were obtained from two meteorological stations of the National Snow and Ice Data Center. The Koilyu Weather Station (KWS, $42^{\circ} 12^{\prime} \mathrm{N}, 79^{\circ}$ $00^{\prime} \mathrm{E}$ and $2800 \mathrm{~m}$ elevation) is a meteorological observatory site in the Kyrgyzstan portion of SRB. The Tienshan Weather Station (TSWS, $41^{\circ} 54^{\prime} \mathrm{N}, 78^{\circ} 12^{\prime} \mathrm{E}$ and $3614 \mathrm{~m}$ elevation) is located next to the northwest boundary of SRB. The monthly meteorological data (including precipitation, maximum temperature and minimum temperature) were available for only 1930-1989 in KWS and 1930-2000 in TSWS.

The monthly APHRODITE data in two grid cells where the KWS and TSWS are located were corrected with observed monthly precipitation and temperature data from the KWS and TSWS stations. The APHRODITE to observation data bias was determined. Daily values of the APHRODITE data in the two grid cells were then corrected based on the derived bias. The corrected daily temperature and precipitation data for the two grid cells were used as the data of the base meteorological stations (KWS and TSWS) in the SWAT model. Temperature and precipitation lapse rates were derived directly from the gridded APHRODITE data at different elevations. The base station temperature and precipitation and their respective lapse rates constituted the meteorological forcing data for the SRB simulation. There were minor refinements of the lapse rates during parameterization.

The climate trend analysis was executed based on the corrected daily data at the KWS and TSWS stations. A detailed description of the analysis is provided in the following sections.

Parameterization. Long-term daily streamflow records for the SRB river systems in the Tianshan Mountains are difficult to find in the public domain. The daily streamflow records were obtained for the XHS from the Hydrological Almanac of China for 1965-1971 and 1980-1989. In addition, monthly streamflow records for 1975-2004 were digitized from published data (Zhao et al., 2013). The daily streamflow data for 1965-1971 were used in the model calibration analysis. Then daily data for 1980-1989 and monthly data for 1975-2004 were used in a validation analysis. The performances of the calibration and validation analyses were evaluated using both the Nash-Sutcliffe efficiency (NSE) and percent bias (PBIAS) indices.

$$
N S E=1-\frac{\sum_{1}^{n}\left(Q_{i}^{\mathrm{obs}}-Q_{i}^{\mathrm{sim}}\right)^{2}}{\sum_{1}^{n}\left(Q_{i}^{\mathrm{obs}}-Q_{\text {mean }}^{\text {obs }}\right)^{2}}
$$

$$
\text { PBIAS }=\frac{\sum_{1}^{n}\left(Q_{i}^{\mathrm{obs}}-Q_{i}^{\mathrm{sim}}\right)}{\sum_{1}^{n}\left(Q_{i}^{\mathrm{obs}}\right)} \times 100
$$

where $Q_{i}^{\text {obs }}$ is the $i$ th observation value for daily flow; $Q_{i}^{\text {sim }}$ is the $i$ th simulation value for daily flow; $Q_{\text {mean }}^{\text {obs }}$ and $Q_{\text {mean }}^{\text {sim }}$ are the means of the observed and simulated data for daily flow; and $n$ is the total number of daily flow observations.

NSE is a normalized statistic that determines the relative degree of residual variance compared with measured data variance. It gives the degree to a plot of observed versus simulated data fits the 1:1 line. NSE ranges between -1 and 1 , with an $N S E=1$ as a perfect fit. PBIAS is the deviation of a simulation from measured data, expressed as a percentage. The optimal value of $P B I A S$ is 0 , with low values indicating accurate model simulation. Positive values indicate model underestimation bias, and negative values indicate model overestimation bias. The modelling performance was also rated using the method adopted by Moriasi et al. (2007), where $0.75<N S E \leq 1.0$ suggests very good, $0.65<N S E \leq 0.75$ good, $0.50<N S E \leq 0.65$ satisfactory and $N S E \leq 0.50$ unsatisfactory simulation results. Also, PBIAS $< \pm 10 \%$ suggests very good, $\pm 10 \% \leq P B I A S< \pm 15 \%$ good, $\pm 15 \% \leq P B I A S< \pm 25 \%$ satisfactory and PBIAS $\geq \pm 25 \%$ unsatisfactory simulation results.

\section{Temperature and precipitation simulation scenarios}

Temperature and precipitation analysis. The trend analysis of the climatic variables was based on the Mann-Kendall test statistic (Hirsch et al., 1982; Gilbert, 1987; Hirsch et al., 1991), a widely used nonparametric analysis in hydrological studies. This test makes no assumptions regarding data distribution and can be used for incomplete seasonal data with serial dependence and linear or nonlinear trends. The Mann-Kendall statistic $(S)$ is computed as follows:

$$
\begin{array}{r}
S=\sum_{k=1}^{n-1} \sum_{j=k+1}^{n} \operatorname{Sgn}\left(x_{j}-x_{k}\right) \\
\operatorname{Sgn}\left(x_{j}-x_{k}\right)=\left\{\begin{array}{cc}
+1 & \left(x_{j}-x_{k}\right)>0 \\
0 & \left(x_{j}-x_{k}\right)=0 \\
-1 & \left(x_{j}-x_{k}\right)<0
\end{array}\right.
\end{array}
$$

where $x_{1}, \ldots, x_{n}$ is the climate variables ordered chronologically and $n$ is the number of points for analysis. For large datasets $(n>40)$, the $Z$-test statistics are given as follows:

$$
Z=\left\{\begin{array}{cc}
\frac{S-1}{\sqrt{\operatorname{Var}(S)}} & S>0 \\
0 & S=0 \\
\frac{S+1}{\sqrt{\operatorname{Var}(S)}} & S<0
\end{array}\right.
$$




$$
\operatorname{Var}(S)=\frac{1}{18}[n(n-1)(2 n+5)]
$$

where $\operatorname{Var}(S)$ is the variance of the data series. The MannKendall test rejects the null hypothesis if $\left(Z \leq-Z_{\mathrm{cr}}\right.$, $Z \geq+Z_{\mathrm{cr}}$ ), where $Z_{\mathrm{cr}}$ is the critical value of normal distribution at the $5 \%$ confidence level $\left(Z_{\mathrm{cr}}=1.96\right)$. Positive $Z$ value indicates increasing trends, while negative $Z$ value designates decreasing trend. A robust estimate of the slope can be calculated using the Sen nonparametric method (Sen, 1968; Gilbert, 1987). In this case, the Sen slope estimator is the median of the $(n-1) / 2$ slopes of the pairs $\left(x_{j}: x_{k}\right)$, where $j>k$.

Based on the trend analysis, climatic variables with significant trends were detrended following the method described by Bouraoui et al. (2004) as follows:

$$
\begin{gathered}
T-\Delta T=T-\beta_{\mathrm{T}} *\left(t_{x}-t_{0}\right) \\
P-\Delta P=P *\left(P_{\mathrm{m}}-\beta_{\mathrm{p}} *\left(t_{x}-t_{0}\right)\right) / P_{\mathrm{m}}
\end{gathered}
$$

where $T-\Delta T$ and $T$ are the detrended and current daily observed temperatures; $P-\Delta P$ and $P$ are the detrended and current daily observed precipitations; $P_{\mathrm{m}}$ is the monthly observed precipitation; $\beta_{\mathrm{T}}$ and $\beta_{\mathrm{P}}$ are the calculated Sen slopes for monthly temperature and precipitation; $t_{0}$ is the base year, which is 1961 in this study; and $t_{x}$ is the current year, which is 1961-2005 in this study. When the calculated detrended value was negative in this study, it was set to the median observed value for that month. The detrended daily temperature $(T-\Delta T)$ and precipitation $(P-\Delta P)$ time series were assumed as the background climatic conditions after removing the effects of climate change.

Scenario analysis. Four different climate scenarios were constructed using different combinations of the temperature and precipitation time series. The combinations were as follows: (i) observed precipitation and observed temperature time series (Scenario 1: $P, T$ ); (ii) observed precipitation and detrended temperature time series (Scenario 2: $P, T-\Delta T$ ); (iii) detrended precipitation and observed temperature time series (Scenario 3: $P-\Delta P, T)$; and (iv) detrended precipitation and detrended temperature series (Scenario 4: $P-\Delta P, T-\Delta T$ ) time series. While Scenario 4 assumed that changes in temperature and precipitation were due to annual variability, Scenario 1 assumed that variations in temperature and precipitation were due not only to annual variability but also to climatic change. The four-scenario simulation laid the basis for the isolation of the impacts of the changes in temperature and precipitation trends on the hydrology of the SRB.

\section{RESULTS}

\section{Model parameters}

Quantifying model sensitivity to input parameters is critical for understanding model performance and subsequent calibration. In glacier-enhanced SWAT model, snow and glacier melt degree-day factors are by far the most sensitive parameters (Immerzeel et al., 2013; Lutz et al., 2013; Lutz et al., 2014). Thus, initial parameter estimates were drawn from the default lower and upper bound values in SWAT database and from other studies in the nearby regions (Wang et al., 2008; Li et al., 2010a; Luo et al., 2012; Wang et al., 2012; Zang et al., 2012; Immerzeel et al., 2013; Luo et al., 2013; Lutz et al., 2013; Lutz et al., 2014). The trial and error method was used to calibrate the glacier-enhanced SWAT model against river discharge at the XHS in daily time step. The optimized values of the most sensitive parameters were used to simulate flow, particularly snowmelt and glacier melt (Table II).

The model performance was assessed by comparing simulated with observed discharge values in calibration and validation analyses. For the calibration analysis, NSE and PBIAS values were respectively 0.66 and 1.65 (Table III). The model performance was rated as 'good' by NSE and 'very good' by PBIAS measures (Moriasi et al., 2007).

During the validation period, the simulated discharges were compared with observed daily (1981-1989) and monthly (1975-2004) values. The model performance was rated as 'good' and even 'very good', respectively, by the NSE and PBIAS measures (Table III).

An assessment of the goodness-of-fit between the model-simulated and observed daily and monthly discharge was based on linear regression analysis (Figure 3a, $\mathrm{b}$ and $\mathrm{c})$. The analysis showed that the simple regression lines were very close to the $1: 1$ line, with a minor $y$-axis intercept suggesting that discharge was slightly underestimated. The coefficients of determination suggested that the simulation accounted for $90 \%$ or more of discharge variations in the study area.

Glaciers in the study area have continuously retreated in recent decades. Although the glacier area loss increased with increasing glacier size in the subbasins, the rate of retreat decreased with increasing glacier size. Also, the glacier retreat decreased with increasing median elevation of the subbasins. The range of glacier area loss in the study area was $0.01-12.46 \mathrm{~km}^{2}$, and the rate of retreat was $1-85 \%$. The basin-wide glacier area decreased by 5.3\% in 1961-2000 and accelerated since the 1970s. Based on the simulation, the rate of retreat was closed to the 5.6\% value of China's Glacier Inventory analysis reported by Gao et al. (2008).

\section{Temperature and precipitation change}

Average annual and monthly temperatures at the KWS and TSWS stations increased in trend with different 
Table II. The most sensitive parameters of the glacier-enhanced SWAT model and the calibrated values for the Sary-Djaz-Kumaric River Basin in the Tianshan Mountains

\begin{tabular}{|c|c|c|c|c|}
\hline Variable & $\begin{array}{l}\text { Sensitive } \\
\text { parameter }\end{array}$ & Parameter definition & $\begin{array}{l}\text { Range of } \\
\text { change }\end{array}$ & Final range \\
\hline Sensitive to & ALPHA_BF & Baseflow alpha factor & $0-1$ & 0.02 \\
\hline baseflow & RCHRG_DP & Deep aquifer percolation factor & $0-1$ & 0.4 \\
\hline $\begin{array}{l}\text { Sensitive to } \\
\text { surface runoff }\end{array}$ & CH_K2 & Channel effective hydraulic conductivity $(\mathrm{mm} / \mathrm{h})$ & $0-300$ & 40 \\
\hline Sensitive to & gmfmx & Glacier melt degree-day factor for $21 \mathrm{June}\left(\mathrm{mm}^{\circ} \mathrm{C}^{-1} \mathrm{day}^{-1}\right)$ & $1.4-16.0$ & $4.3-12.8$ \\
\hline glacier melt & gmfmn & Glacier melt degree-day factor for 21 December $\left(\mathrm{mm}^{\circ} \mathrm{C}^{-1}\right.$ day $\left.^{-1}\right)$ & $1.4-16.0$ & $1.7-8.0$ \\
\hline Sensitive to & SMFMX & Snow melt factor for $21 \mathrm{June}\left(\mathrm{mm}^{\circ} \mathrm{C}^{-1}\right.$ day $\left.^{-1}\right)$ & $1.4-6.7$ & 3.3 \\
\hline snowmelt & SMFMN & Snow melt factor for 21 December $\left(\mathrm{mm}^{\circ} \mathrm{C}^{-1}\right.$ day $\left.^{-1}\right)$ & $1.4-6.7$ & 2.5 \\
\hline
\end{tabular}

Table III. NSE, PBIAS and $R^{2}$ statistics for simulated daily discharge in the Sary-Djaz-Kumaric River Basin in the Tianshan Mountains using the glacier-enhanced SWAT model

\begin{tabular}{lcclrr}
\hline Analysis & Stage & NSE & Rating & PBIAS (\%) & Rating \\
\hline Calibration & $1965-1971$ & 0.66 & Good & 1.55 & 0.69 \\
Validation & $1981-1989$ & 0.71 & Good & -5.66 & Very good \\
& $1975-2004$ & 0.89 & Very good & -0.09 & 0.74 \\
\hline
\end{tabular}

statistical significances during 1961-2005 (Figure 4). Analysis based on data from the two stations suggested annual temperature increase of $0.03^{\circ} \mathrm{C} /$ year $(p=0.05)$. The temperature increase was mainly in snowfall and glacier melt seasons. Temperature increase in the KWS station was $0.07{ }^{\circ} \mathrm{C} /$ year in February, $0.04{ }^{\circ} \mathrm{C} /$ year in September and $0.07^{\circ} \mathrm{C} /$ year in November $(p=0.01)$. Then, temperature increase in the TSWS station was $0.07^{\circ} \mathrm{C} /$ year in February, $0.03^{\circ} \mathrm{C} /$ year in July, $0.02{ }^{\circ} \mathrm{C} /$ year in August and $0.05^{\circ} \mathrm{C} /$ year in September $(p=0.01)$. Temperature also increased in other months, but at lower significance levels.

Detrended temperature analysis was also performed for September through February in the KWS station and for February, June to September and November in the TSWS station. At the basin scale, the average annual temperature increased by $0.6^{\circ} \mathrm{C}$ during the period 1961-2005 (Figure 5a). The rate of increase in 1961-1980 was $0.01^{\circ} \mathrm{C} /$ year and that in 1981-2005 was $0.03^{\circ} \mathrm{C} /$ year. Temperature mainly increased in September through February (Figure 5b), suggesting a prolonged glacier melt season, as also noted by Osmonov et al. (2013).

In the KWS and TSWS meteorological stations, annual precipitation for 1961-2005 slightly increased at a statistically insignificant trend (Figure 4). Annual precipitation increased by $0.5 \mathrm{~mm} /$ year in the KWS station and by $0.3 \mathrm{~mm} /$ year in the TSWS station. Precipitation increase in March and October was significant at $p=0.05$. However, precipitation in the other months either increased or decreased at an insignificant rate. The change in the basin-averaged precipitation was similar to that in the meteorological stations. Note that the detrended precipitation analyses for the months of March and October had significant increasing trends.

\section{Changes in snow and glacier melt}

The effects of temperature and precipitation change on snowmelt varied seasonally (Figure 6a). Snowmelt was mainly in March through October, with maximum melt in May. Snowmelt seldom occurred in November and February, except at lower altitudes where temperatures were higher. The increased snowmelt in April and May was attributed to high snow accumulation in winter, which was due to significant increase in precipitation in October and in March of the previous year. However, in July through September, snowmelt decreased because of less snowfall and high evaporation loss driven by the rising temperatures.

On average, annual snowmelt in 1961-2005 increased by $1.3 \%$ (mainly because of increased precipitation in October and March). Precipitation increase led to $4.2 \%$ increase in snow accumulation and thus snowmelt. This was negated by $3.0 \%$ decrease in snow accumulation and thus snow melt driven by increasing temperatures (Table IV).

Glacier melt was in April to September and that in June and August accounted for $84 \%$ of annual glacier melt in the basin, and with peak melt in July. Glacier melt includes supraglacial snow and ice melt (Figure 6b, c and d). Under Scenario 1, average supraglacial snow melt accounted for $49 \%$ of total glacier melt in 1961-2005. The slight increase in supraglacial snow melt in the months of June and July (Figure 6c) was attributed to a possible increase in supraglacial snow accumulation in the preceding season. Comparison of Scenario $4(P-\Delta P, T-\Delta T)$ with Scenario $1(P, T)$ revealed a significant increase in supraglacial snow 

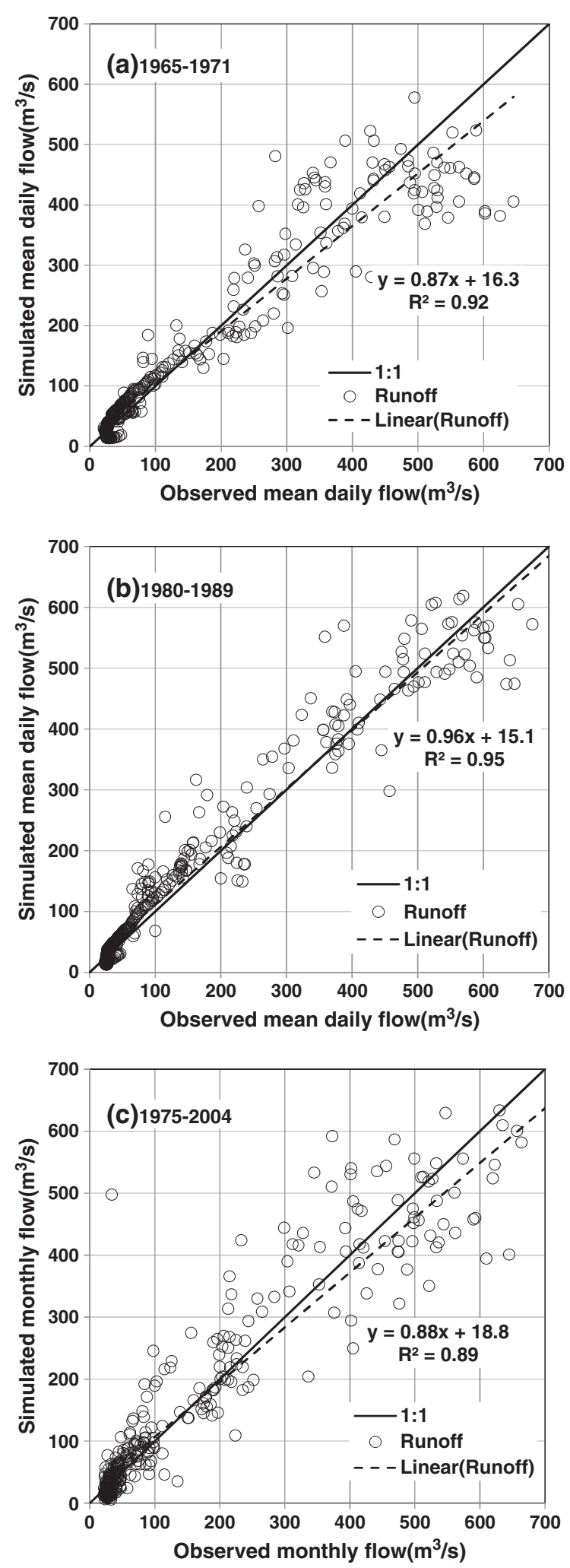

Figure 3. Comparisons between simulated and measured daily (1965-1971 and 1980-1989) and monthly (1975-2004) streamflows in the Sary-Djaz-Kumaric River Basin for the calibration (1965-1971) and validation (1980-1989 and 1975-2004) periods melt in September. This suggested that significant temperature rise in September enhanced supraglacial snow melt in the study area. Rising temperatures also enhanced ice melt, especially in September during which month temperature significantly increased (Figure 6d).

Increase in both temperature and precipitation led to an increase in glacier melt, with rising temperature as the main driving factor. While temperature rise enhanced both supraglacial snow and ice melt, precipitation increase resulted in more supraglacial snow melt than ice melt. Average annual supraglacial snow melt in 1961-2005 increased by $4.7 \%, 3.3 \%$ of which was due to the temperature rise and $1.3 \%$ to precipitation increase. Temperature rise increased annual ice melt by $6.1 \%$, $0.5 \%$ of which was negated by precipitation increase. Glacier melt increased by $5.4 \%$, also $5.0 \%$ of which was due to temperature rise and $0.4 \%$ to precipitation increase (Table IV).

\section{Change in streamflow}

Streamflow increased because of increasing temperature and precipitation in recent decades. On average, streamflow increased by $4.4 \%$ from 1961 to 2005 . Temperature rise and precipitation increase contributed to $2.5 \%$ and $1.9 \%$ of the increase in streamflow, respectively (Table IV). This suggests that temperature more dominantly affects streamflow in the basin.

Snow and glacier melt were the dominant source of streamflow in the study area, respectively, contributing $42 \%$ and $52 \%$ to the basin discharge. In fact, these are the components of runoff that are most sensitive to climatic change. The increase in snow and glacier melt due to increasing precipitation and temperature increased streamflow with significant seasonal variability. Streamflow slightly increased in April and May because of increased snow melt. It also slightly increased in June through August because of the combined effects of decreasing snow melt, increasing glacier melt and high evaporation under warming climatic conditions. Moreover, the increase in the contribution of glacier melt to streamflow was slightly larger than that of snow melt and evaporation combined. The most significant increase in streamflow was in September, attributed to enhanced glacier melt driven by rising temperatures. Streamflow due to temperature rise increased by $30 \%$ in September (Figure 6e). Changes in streamflow in the other months were not so obvious. Compared with Scenario 4 (detrended condition: $P-\Delta P$, $T-\Delta T)$, there was no shift in the streamflow hydrograph, despite the higher magnitude peak flow.

The impacts of temperature and precipitation change on streamflow were especially significant after 1980 (Figure 7). Compared with the detrended scenario $(P-\Delta P$, $T-\Delta T$ ), temperature increased by 0.2 and $0.8^{\circ} \mathrm{C}$ while precipitation increased by 5.8 and $15.8 \mathrm{~mm}$, respectively, 


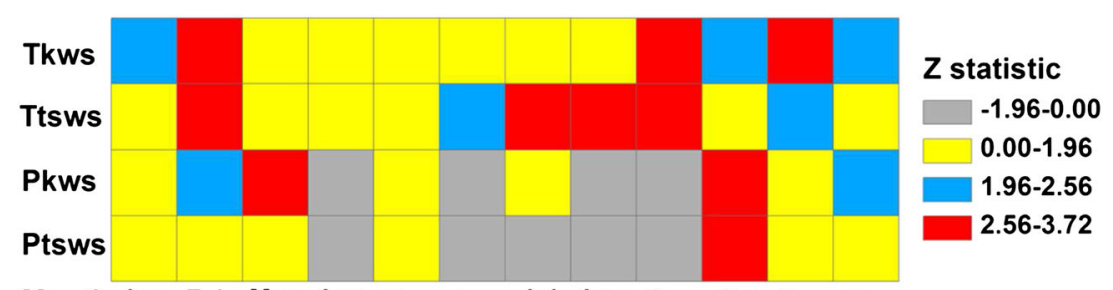

Month Jan Feb Mar Apr May Jun Jul Aug Sep Oct Nov Dec

Figure 4. Plot of Z-statistic of monthly precipitation (Pkws and Ptsws) and temperature (Tkws and Ttsws) for the period 1961-2005 at the Koilyu Weather Station (KWS) and Tienshan Weather Station (TSWS)
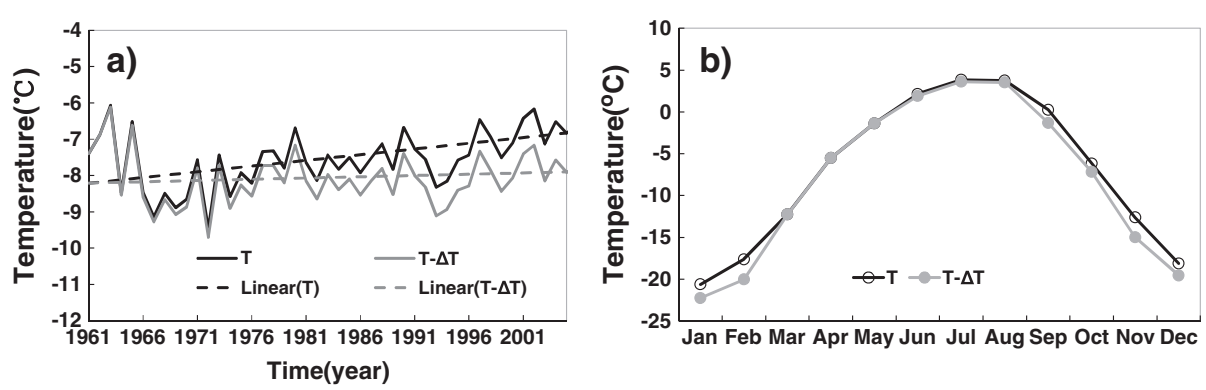

Figure 5. Plots of observed $(T)$ and detrended $(T-\Delta T)$ average annual and monthly temperature for the period 1961-2005 in the Sary-Djaz-Kumaric River Basin

in 1961-1980 and 1981-2005. Subsequently, mean annual discharge increased by $0.8 \times 10^{8}$ and $2.8 \times 10^{8} \mathrm{~m}^{3}$, respectively, in 1961-1980 and 1981-2005. The increase in streamflow in 1981-2005 was mainly attributed to accelerated glacier melt driven by temperature rise. Increase in glacier melt accounted for $\sim 65 \%$ increase in streamflow in the study area.

\section{DISCUSSIONS}

\section{Detrending technique}

While there is a huge number of studies around the world on the impact of climate change on watershed hydrological processes, most of these studies have focused on projections of future hydrological conditions (Liu et al., 2010; Miller et al., 2012; Huss et al., 2014; Pellicciotti et al., 2014; Tao et al., 2014; Yucel et al., 2015). On the contrary, this study used historical records to determine the effects of temperature and precipitation change on watershed hydrological processes. Statistical techniques are often used to establish regression relations between runoff and temperature and precipitation in order to explain the causes and effects of climate change on variations in runoff (McBean and Motiee, 2008; Monk et al., 2011; Bocchiola, 2014; Madsen et al., 2014; Moran-Tejeda et al., 2014). In this study, however, an integrative approach based on physically based glaciohydrological modelling and climate data series detrending was used to isolate and quantify the respective effects of temperature and precipitation on glacio-hydrological processes such as snowmelt and glacier melt and streamflow. Chen et al. (2006) and Sorg et al. (2012) reported an increasing trend in streamflow in the investigated SRB. In this study, an increasing trend in streamflow was also noted, driven mainly by accelerated glacier melt that was in turn induced by a significant rise in temperature in the glacierized basin. Average annual streamflow in the SRB increased by $4.4 \%(16.1 \mathrm{~mm})$ in $1961-2005,2.5 \%(9.3 \mathrm{~mm})$ of which was due to rising temperature and $1.9 \%(7.1 \mathrm{~mm})$ to increasing precipitation. Of the $9.3 \mathrm{~mm}$ increase in streamflow due to temperature rise, 9.4 and $6.2 \mathrm{~mm}$ were respectively contributed by the increasing glacier melt and ice melt (Table IV). Although some studies have put forward qualitative descriptions and inferences regarding glaciohydrological processes, rigorous quantitative conclusions remain largely lacking. Studies have used correlation (not quantitative) analysis at various temporal scales to suggest that rather than the increase in precipitation, the rise in temperature was the cause of increasing discharge of glacier-melt-fed rivers in the Tianshan Mountains in the last half-century (Wang et al., 2013; Xu et al., 2013a; Kundzewicz et al., 2015). Li et al. (2010b) attributed the increase in runoff in the headwater regions of the Urumqi River in eastern Tianshan in 1959-2006 largely to increasing glacier melt and additional to the increasing precipitation without quantifying their relative contribution ratios. Savitskiy et al. (2008) explained the increasing runoff in the Naryn River by a reduction in glacier area due to lack of evidence of corresponding change in precipitation. Although Lutz et al. (2014) forwarded some quantitative results and projected that increase in precipitation would be the main driver of 

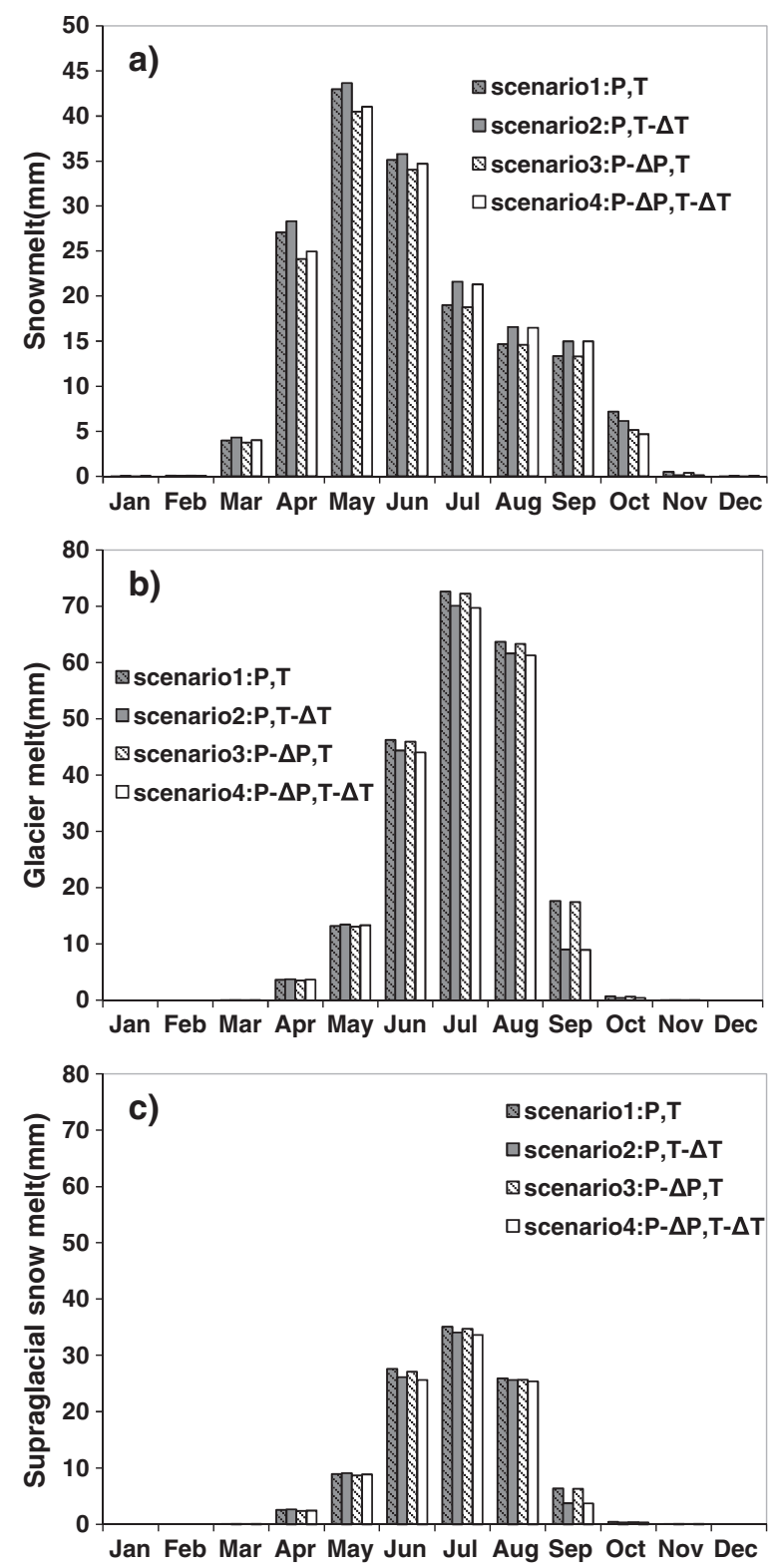

Figure 6. Seasonal distributions of snow, glacier, supraglacial snow and ice melts and streamflow in 1961-2005 under four scenario simulations for the Sary-Djaz-Kumaric River Basin

increasing runoff in rain-runoff-dominated or snowmeltdominated rivers and that accelerated melt by rising temperature in glacier-melt dominated rivers, the study was over-reliant on projected climate data and could not explain the observed runoff changes.

Several studies have used statistical analysis to investigate the relationship between discharge and climate change due mainly to the relative simplicity of such analysis. Also, some studies have correlated discharge with meteorological data in glacierized basins via regression models (Singh et al., 2000; Archer and Fowler, 2008; Wang et al., 2013; Xu et al., 2013a). Regression
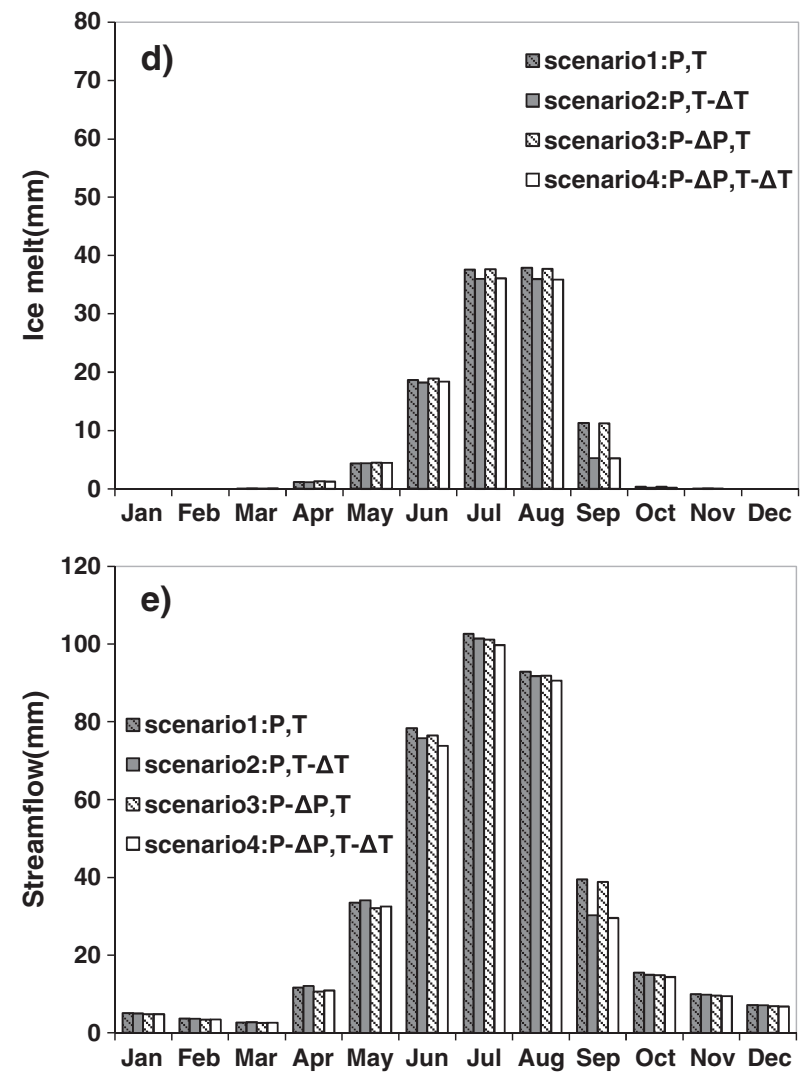

Figure 6. (Continued)

and/or correlation analyses establish cause-effect relations in an easy-to-use way and can associate discharge with climatic factors. However, such analyses are generally not well suited for quantifying the impacts of temperature and precipitation changes on runoff components such as snow and glacier melt.

Physically based glacio-hydrological models are much more powerful tools for process-based analysis of the effects of climate change on runoff, and especially those involving projections of future effects. The temporal analysis method used in this study illustrated the impacts of climate change on streamflow. This technique has previously been used to analyse the impacts of climate change on watershed hydrological processes through hydrological simulation (Bouraoui et al., 2004). In this study, the glacier-enhanced SWAT model simulation (driven by observed and detrended temperature and precipitation data) quantified the individual and combined effects of temperature and precipitation on runoff and hence on streamflow (Table IV). The observation datadriven analysis was promising in determining the effects of climatic change on hydrological processes. This was especially useful for supporting a better understanding on past, current and future hydrological processes in glacierized basins. 
Table IV. Quantitative impacts of temperature $(T)$ and precipitation $(P)$ on average annual discharge, snowmelt and glacier melt in 1961-2005 in the Sary-Djaz-Kumaric River Basin in the Tianshan Mountains

\begin{tabular}{|c|c|c|c|c|c|c|c|c|c|}
\hline \multirow[b]{2}{*}{ Variables } & & \multirow{2}{*}{$\begin{array}{c}P \\
(\mathrm{~mm})\end{array}$} & \multirow{2}{*}{$\begin{array}{c}T \\
\left({ }^{\circ} \mathrm{C}\right)\end{array}$} & \multicolumn{2}{|c|}{ Discharge } & \multirow{2}{*}{$\begin{array}{l}\text { Snowmelt } \\
(\mathrm{mm})\end{array}$} & \multirow{2}{*}{$\begin{array}{c}\text { Glacier } \\
\text { melt } \\
(\mathrm{mm})\end{array}$} & \multirow{2}{*}{$\begin{array}{c}\text { Ice } \\
\text { melt } \\
(\mathrm{mm})\end{array}$} & \multirow{2}{*}{$\begin{array}{c}\text { Supraglacial } \\
\text { snowmelt } \\
(\mathrm{mm})\end{array}$} \\
\hline & & & & $\left(10^{8} \mathrm{~m}^{3}\right)$ & $(\mathrm{mm})$ & & & & \\
\hline \multirow[t]{4}{*}{ Scenarios } & $P, T$ & 492 & -7.6 & 49.36 & 383 & 163 & 198.7 & 100.8 & 97.8 \\
\hline & $P, T-\Delta T$ & 492 & -8.2 & 48.20 & 374 & 167 & 189.3 & 94.6 & 94.6 \\
\hline & $P-\Delta P, T$ & 480 & -7.6 & 48.48 & 376 & 156 & 197.9 & 101.3 & 96.6 \\
\hline & $P-\Delta P, T-\Delta T$ & 480 & -8.2 & 47.29 & 367 & 161 & 188.5 & 95.1 & 93.4 \\
\hline \multirow[t]{3}{*}{ Offsets } & $P-\Delta P, T$ & 0.0 & 0.6 & 1.2 & 9.3 & -4.8 & 9.4 & 6.2 & 3.1 \\
\hline & $P, T-\Delta T$ & 12.4 & 0.0 & 0.9 & 7.1 & 6.8 & 0.8 & -0.5 & 1.2 \\
\hline & $P, T$ & 12.4 & 0.6 & 2.1 & 16.1 & 2.1 & 10.2 & 5.8 & 4.4 \\
\hline \multirow[t]{3}{*}{ Relative offsets } & $\Delta T$ & 0.0 & & 2.5 & 2.5 & -3.0 & 5.0 & 6.6 & 3.3 \\
\hline & $\Delta P$ & 2.6 & & 1.9 & 1.9 & 4.2 & 0.4 & -0.5 & 1.3 \\
\hline & $\Delta T$ and $\Delta P$ & 2.6 & & 4.4 & 4.4 & 1.3 & 5.4 & 6.1 & 4.7 \\
\hline
\end{tabular}

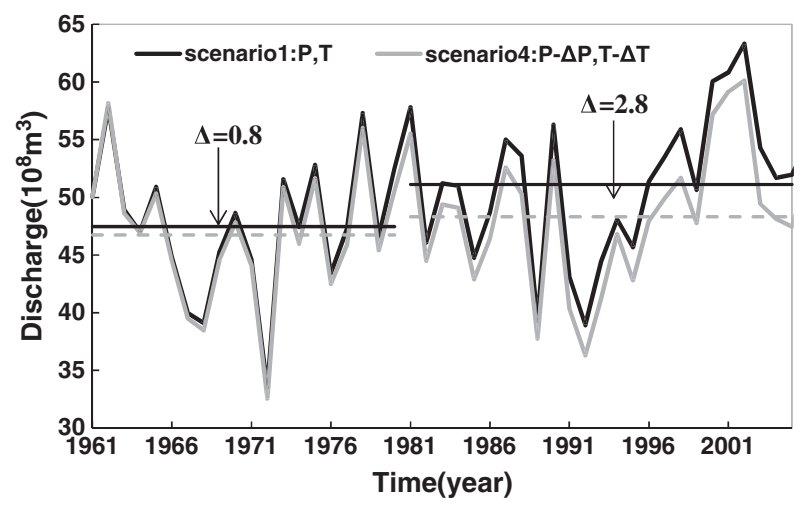

Figure 7. Variations in annual river discharge in 1961-2005 under four scenario conditions in the Sary-Djaz-Kumaric River Basin

\section{Model uncertainties}

Despite the good results, however, uncertainties still existed in the study. The uncertainties could have come from different aspects of the hydrological simulation, including the input data, model structure and parameterization process.

For data-scarce high alpine catchments, glaciohydrological simulations are limited by lack of sufficient data. Thus, this study used APHRODITE data as there was only one metrological station in the study area with another station in the nearby region. Although the gridded APHRODITE dataset was corrected for bias using observation data, temperature and precipitation lapse rates were based on the raw APHRODITE data. This could induce uncertainties in the climate input, given the spatial heterogeneity of climate in large regions. The combined use of NSE and PBIAS could make a more reliable judgement of model performance (Luo et al., 2013). Figure 8 shows that the uncertainty in Plaps was much larger than that in Tlaps. When Plaps $=168 \mathrm{~mm} / \mathrm{km}$, streamflow was slightly underestimated but still 'good' enough (Moriasi et al., 2007). Then when Tlaps $=-6.2^{\circ} \mathrm{C} / \mathrm{km}$, the model
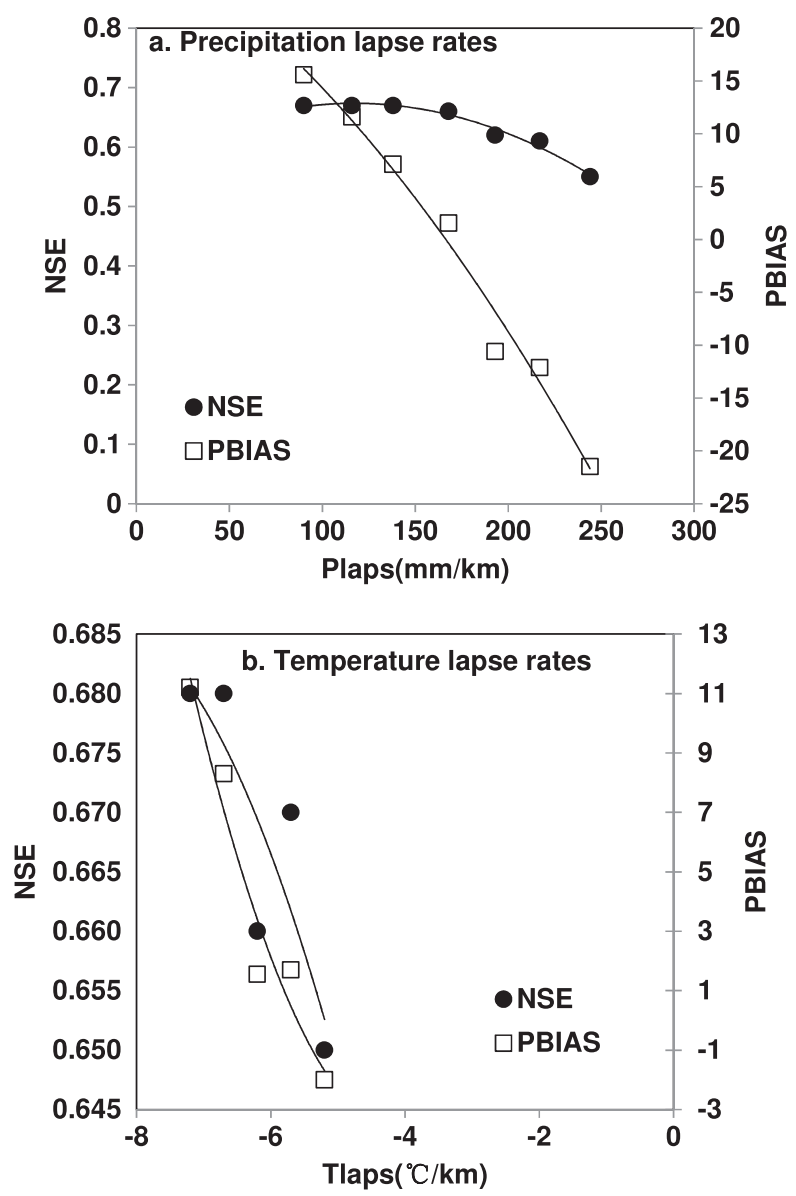

Figure 8. Plots of sensitivities of precipitation and temperature lapse rates to simulated streamflow, NSE and PBIAS

simulation achieved 'good' performance. Thus, temperature and precipitation in the subbasins and the entire catchment were subsequently obtained using the lapse rates. Table $\mathrm{V}$ shows the seasonal distributions of temperature and precipitation before and after bias 
correction through the lapse rates. Then Figure 9 depicts the spatial distribution of the bias-corrected annual temperature and precipitation in the study area.
This study used temporal analysis and the Mann-Kendall test to remove precipitation and temperature linearity. As discussed earlier, long-term changes in temperature and

Table V. Biases in average annual and seasonal precipitation and temperature without correction for APHRODITE grids compared with simulated subbasin precipitation and temperature through lapse rates

\begin{tabular}{llrrrrr}
\hline & Annual & Spring & Summer & Autumn & Winter \\
\hline Precipitation & APHRODITE (mm) & 324.2 & 82.9 & 155.9 & 61.5 & 23.8 \\
& Simulated (mm) & 491.9 & 115.3 & 284.1 & 71.0 & 21.5 \\
& Relative error $(\%)$ & 34.1 & 28.1 & 45.1 & 13.3 & -10.9 \\
Temperature & -3.6 & -2.6 & 7.5 & -3.1 & -16.3 \\
& APHRODITE $\left({ }^{\circ} \mathrm{C}\right)$ & -7.6 & -6.9 & 2.8 & -6.9 & -19.5 \\
& Simulated $\left({ }^{\circ} \mathrm{C}\right)$ & -4.0 & -4.3 & -4.7 & -3.7 & -3.2 \\
& Bias $\left({ }^{\circ} \mathrm{C}\right)$ & & & & \\
\hline
\end{tabular}
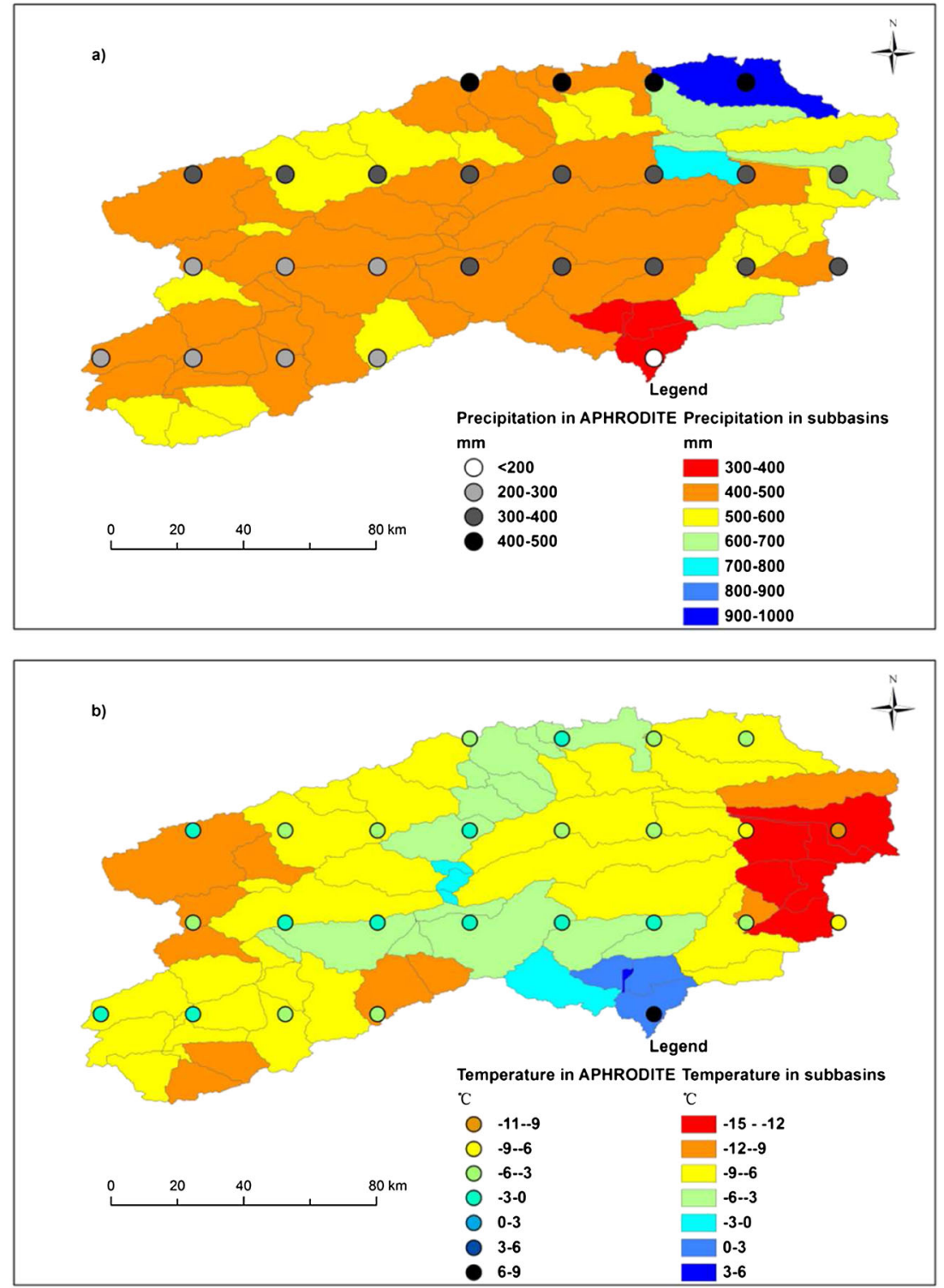

Figure 9. Comparison between the average annual precipitation (a) and temperature (b) without correction for APHRODITE grids and simulated precipitation and temperature of subbasins using lapse rates 
precipitation can be nonlinear (Sorg et al., 2012; UngerShayesteh et al., 2013; Xu et al., 2013b; Chen et al., 2014). Thus, a nonlinear trend analysis in conjunction with detrended analysis could provide much better understanding of the impacts of climate change on long-term glaciohydrological processes in snow/glacier-driven catchments.

Uncertainty induced by hydrological model and simulation is still a common issue to be addressed, e.g. problem of nonlinearity, the problem of scale and the problem of equifinality as reviewed by Beven (2001). The updated distributed hydrological model with glacier hydrology module makes the issue even more complicated. Glacier is a unique hydrological response unit storing precipitation as solid and releasing it as liquid water with delay at variable time scales. Its compensation effects to precipitation could induce uncertainties in watershed water balance. However, the additional information on glacier area change and mass balance could enhance model parameterization and watershed water balance if precipitation input is with acceptable accuracy (Hagg et al., 2013; Luo et al., 2013). Irrespectively, difficulties still remain in highly glacierized alpine watersheds because of the scarcity of both climatic and glacier observation data. Application of the gridded climatic datasets as a proxy (Immerzeel et al., 2012; Hagg et al., 2013; Lutz et al., 2013; Lutz et al., 2014) and remote sensing imaging of glacier change (Bolch, 2007; Pandey and Venkataraman, 2013; Immerzeel et al., 2014; Sorg et al., 2014) seems promising in tackling these difficulties, at least to some extent.

Although the 'lumped' glacier approach has been widely used in basin-wide glacier melt simulations (Stahl et al., 2008; Jost et al., 2012; Lutz et al., 2013), errors and its magnitude induced by lumping individual glaciers into a 'big' glacier are rarely discussed in the literature. The volume-area scaling relation established for individual glaciers is also widely used in glacier hydrology studies (Hirabayashi et al., 2010; Konz and Seibert, 2010). However, the parameters for such relations are obtained from individual (often small) glacier measurements. The 'lumping' approach integrates individual glaciers of different sizes into a 'big' glacier and could thereby induce uncertainties (due to nonlinearity of glacier volume and area) in glacier hydrology simulation. The reliability of extending the relation to large glaciers has still not been fully tested because of limited data availability, requiring focused study in this regard.

\section{CONCLUSIONS}

This study quantified the relative impacts of precipitation and temperature on runoff in the SRB of the Tianshan Mountains for the period 1961-2005. We conducted a detrended analysis of the forcing climate data and the physically based, spatially distributed and glacierenhanced SWAT model.

The basin-wide average annual temperature increased by $0.6^{\circ} \mathrm{C}$ in $1961-2005$. Temperature increase in 1961-1980 was $0.01^{\circ} \mathrm{C} /$ year while that in 1981-2005 was $0.03{ }^{\circ} \mathrm{C} /$ year. Moreover, temperature increase was mainly in September through February the following year. Annual precipitation slightly increased in 19612005 , but at a insignificant rate. Although precipitation increase in March and October was significant $(p=0.05)$, precipitation increase or decrease in the other months was also statistically insignificant.

For 1961-2005, annual snowmelt increased by $1.3 \%$ due mainly to increasing precipitation in March and October. The increase in precipitation resulted in $4.2 \%$ increase in snow accumulation and thus snowmelt. The effect of this increase was negated by $3.0 \%$ decrease in snow accumulation and thus snow melt due to rising temperature.

Although the increase in both temperature and precipitation triggered more glacier melt, the effect of temperature rise was higher than that of precipitation increase on glacier melt. Temperature rise increased annual ice melt by as much as $6.6 \%, 0.5 \%$ of which was negated nevertheless by precipitation increase. Glacier melt increased by $5.4 \%, 5.0 \%$ of which was due to temperature rise and $0.4 \%$ to precipitation increase.

The increase in streamflow was largely attributed to the significant rise in temperature. Average annual streamflow increased by $4.4 \%$ in $1961-2005,2.5 \%$ of which was due to temperature rise and $1.9 \%$ to precipitation increase.

This paper discussed the specific drivers and processes of observed runoff patterns in the study area; thus, the analyses therein were sufficient for the conclusions reached. Thus, the method adopted in this study could be applicable in other river basins around the world with similar hydrological conditions. This is important for efficient management of limited and fast-depleting global water resources.

\section{ACKNOWLEDGEMENTS}

This study was funded by the Natural Science Foundation of China (grant no. 41130641) and the Ministry of Science and Technology of China (grant no. 2010DFA92720; grant no. 2012BAC19B07). We are grateful for the constructive inputs by the anonymous reviewers and editors in the review phase of the paper.

\section{REFERENCES}

Aizen VB, Aizen EM, Melack JM, Dozier J. 1997. Climatic and hydrologic changes in the Tien Shan, Central Asia. Journal of Climate 10: $1393-1404$.

Archer DR, Fowler HJ. 2008. Using meteorological data to forecast seasonal runoff on the River Jhelum, Pakistan. Journal of Hydrology 361: 10-23. DOI:10.1016/j.jhydrol.2008.07.017. 
Arendt A, Bolch T, Cogley JG, Gardner A, Hagen J-O, Hock R, Kaser G, Pfeffer WT, Moholdt G, Paul F, Radić V, Andreassen L, Bajracharya S, Barrand N, Beedle M, Berthier E, Bhambri R, Bliss A, Brown I, Burgess D, Burgess E, Cawkwell F, Chinn T, Copland L, Davies B, De Angelis H, Dolgova E, Filbert K, Forester RR, Fountain A, Frey H, Giffen B, Glasser N, Gurney S, Hagg W, Hall D, Haritashya UK, Hartmann G, Helm C, Herreid S, Howat I, Kapustin G, Khromova T, Kienholz C, Köonig M, Kohler J, Kriegel D, Kutuzov S, Lavrentiev I, Le Bris R, Lund J, Manley W, Mayer C, Miles E, Li X, Menounos B, Mercer A, Mölg N, Mool P, Nosenko G, Negrete A, Nuth C, Pettersson R, Racoviteanu A, Ranzi R, Rastner P, Rau F, Raup B, Rich J, Rott H, Schneider C, Seliverstov Y, Sharp M, Sigurðsson O, Stokes C, Wheate R, Winsvold S, Wolken G, Wyatt F, Zheltyhina N. 2012. Randolph Glacier Inventory - A dataset of global glacier outlines: version 3.2. Global Land Ice Measurements from Space: Boulder Colorado, USA. Digital Media.

Arnold JG, Moriasi DN, Gassman PW, Abbaspour KC, White MJ, Srinivasan R, Santhi C, Harmel RD, van Griensven A, Van Liew MW, Kannan N, Jha MK. 2012. SWAT: model use, calibration, and validation. Transactions of the ASABE 55: 1491-1508.

Arnold JG, Srinivasan R, Muttiah RS, Williams JR. 1998. Large area hydrologic modeling and assessment part I: model development 1. JAWRA Journal of the American Water Resources Association 34: $73-89$.

Bahr DB, Pfeffer WT, Kaser G. 2015. A review of volume-area scaling of glaciers. Reviews of Geophysics 53: 2014RG000470. DOI: 10.1002/ $2014 \mathrm{rg} 000470$

Beven K. 2001. How far can we go in distributed hydrological modelling? Hydrology and Earth System Sciences 5: 1-12.

Bliss A, Hock R, Radic V. 2014. Global response of glacier runoff to twenty-first century climate change. Journal of Geophysical ResearchEarth 119: 717-730. DOI: $10.1002 / 2013$ jf002931.

Bocchiola D. 2014. Long term (1921-2011) hydrological regime of Alpine catchments in Northern Italy. Advances in Water Resources 70: 51-64. DOI:10.1016/j.advwatres.2014.04.017.

Bolch T. 2007. Climate change and glacier retreat in northern Tien Shan (Kazakhstan/Kyrgyzstan) using remote sensing data. Global and Planetary Change 56: 1-12. DOI:10.1016/j.gloplacha.2006.07.009.

Bouraoui F, Grizzetti B, Granlund K, Rekolainen S, Bidoglio G. 2004. Impact of climate change on the water cycle and nutrient losses in a Finnish catchment. Climatic Change 66: 109-126.

Campbell JL, Driscoll CT, Pourmokhtarian A, Hayhoe K. 2011. Streamflow responses to past and projected future changes in climate at the Hubbard Brook Experimental Forest, New Hampshire, United States. Water Resources Research 47: . DOI:10.1029/2010wr009438.

Carrivick JL, Brewer TR. 2004. Improving local estimations and regional trends of glacier equilibrium line altitudes. Geografiska Annaler: Series A, Physical Geography 86: 67-79.

Chen J, Ohmura A. 1990. Estimation of alpine glacier water resources and their change since the 1870s. Hydrology in mountainous regions - I. Hydrologic measurements, the water cycle. In: Proceedings of the Two Lausanne Symposia, IAHS Publ. No. 193: 127-135.

Chen Y, Takeuchi K, Xu C, Chen Y, Xu Z. 2006. Regional climate change and its effects on river runoff in the Tarim Basin, China. Hydrological Processes 20: 2207-2216.

Chen YN, Deng HJ, Li BF, Li Z, Xu CC. 2014. Abrupt change of temperature and precipitation extremes in the arid region of Northwest China. Quaternary International 336: 35-43. DOI:10.1016/j. quaint.2013.12.057.

Chen ZS, Chen YN. 2014. Effects of climate fluctuations on runoff in the headwater region of the Kaidu River in northwestern China. Frontiers of Earth Science 8: 309-318. DOI:10.1007/s11707-014-0406-2.

Dahlke HE, Lyon SW, Stedinger J, Rosqvist G, Jansson P, Weiler M. 2012. Contrasting trends in floods for two sub-arctic catchments in northern Sweden - does glacier presence matter? Hydrology and Earth System Sciences 16: 2123-2141. DOI:10.5194/hess-16-2123-2012.

Fan YT, Chen YN, Li WH, Wang HJ, Li XG. 2011. Impacts of temperature and precipitation on runoff in the Tarim River during the past 50 years. Journal of Arid Land 3: 220-230. DOI:10.3724/sp. j.1227.2011.00220.

Gao QZ, Wang R, Ernst G. 2008. Impact of climate change on surface runoff of Tarim River originating from the south slopes of the
Tianshan Mountains. Journal of Glaciology and Geocryology 30: 1-11 (in Chinese).

Gassman PW, Reyes MR, Green CH, Arnold JG. 2007. The Soil and Water Assessment Tool: historical development, applications, and future research directions. Transactions of the ASABE 50: 1211-1250.

Gilbert RO. 1987. Statistical methods for environmental pollution monitoring. John Wiley \& Sons: New York.

Guo WQ, Liu SY, Xu JL, Wu LZ, Shangguan DH, Yao XJ, Wei JF, Bao WJ, Yu PC, Liu Q, Jiang ZL. 2015. The second Chinese glacier inventory: data, methods and results. Journal of Glaciology 61: 357-372.

Hagg W, Braun LN, Kuhn M, Nesgaard TI. 2007. Modelling of hydrological response to climate change in glacierized Central Asian catchments. Journal of Hydrology 332: 40-53. DOI:10.1016/j. jhydrol.2006.06.021.

Hagg W, Hoelzle M, Wagner S, Mayr E, Klose Z. 2013. Glacier and runoff changes in the Rukhk catchment, upper Amu-Darya basin until 2050. Global and Planetary Change 110: 62-73. DOI:10.1016/j. gloplacha.2013.05.005

Hirabayashi Y, Doll P, Kanae S. 2010. Global-scale modeling of glacier mass balances for water resources assessments: glacier mass changes between 1948 and 2006. Journal of Hydrology 390: 245-256. DOI:10.1016/j.jhydrol.2010.07.001.

Hirsch RM, Alexander RB, Smith RA. 1991. Selection of methods for the detection and estimation of trends in water quality. Water Resources Research 27: 803-813.

Hirsch RM, Slack JR, Smith RA. 1982. Techniques of trend analysis for monthly water quality data. Water Resources Research 18: 107-121.

Huss M, Zemp M, Joerg PC, Salzmann N. 2014. High uncertainty in 21st century runoff projections from glacierized basins. Journal of Hydrology 510: 35-48. DOI:10.1016/j.jhydrol.2013.12.017.

Immerzeel WW, Kraaijenbrink PDA, Shea JM, Shrestha AB, Pellicciotti F, Bierkens MFP, de Jong SM. 2014. High-resolution monitoring of Himalayan glacier dynamics using unmanned aerial vehicles. Remote Sensing of Environment 150: 93-103. DOI:10.1016/j.rse.2014.04.025.

Immerzeel WW, Pellicciotti F, Bierkens MFP. 2013. Rising river flows throughout the twenty-first century in two Himalayan glacierized watersheds. Nature Geoscience 6: 742-745. DOI:10.1038/ngeo1896.

Immerzeel WW, van Beek LPH, Konz M, Shrestha AB, Bierkens MFP. 2012. Hydrological response to climate change in a glacierized catchment in the Himalayas. Climatic Change 110: 721-736. DOI:10.1007/s10584-011-0143-4.

IPCC. 2013. Climate Change 2013: The Physical Science Basis. Contribution of Working Group I to the Fifth Assessment Report of the Intergovernmental Panel on Climate Change. Cambridge University Press, Cambridge, United Kingdom and New York, NY, USA.

Jost G, Moore R, Menounos B, Wheate R. 2012. Quantifying the contribution of glacier runoff to streamflow in the upper Columbia River Basin, Canada. Hydrology and Earth System Sciences 16: 849-860. DOI: $10.5194 /$ hess-16-849-2012.

Karlsson IB, Sonnenborg TO, Jensen KH, Refsgaard JC. 2014. Historical trends in precipitation and stream discharge at the Skjern River catchment, Denmark. Hydrology and Earth System Sciences 18: 595-610. DOI:10.5194/hess-18-595-2014.

Khaliq MN, Ouarda TBMJ, Gachon P. 2009. Identification of temporal trends in annual and seasonal low flows occurring in Canadian rivers: the effect of short- and long-term persistence. Journal of Hydrology 369: 183-197. DOI:10.1016/j.jhydrol.2009.02.045.

Konz M, Seibert J. 2010. On the value of glacier mass balances for hydrological model calibration. Journal of Hydrology 385: 238-246. DOI:10.1016/j.jhydrol.2010.02.025.

Kundzewicz ZW, Merz B, Vorogushyn S, Hartmann H, Duethmann D, Wortmann M, Huang S, Su B, Jiang T, Krysanova V. 2015. Analysis of changes in climate and river discharge with focus on seasonal runoff predictability in the Aksu River Basin. Environmental Earth Sciences 73: 501-516. DOI:10.1007/s12665-014-3137-5.

Kure S, Jang S, Ohara N, Kavvas ML, Chen ZQ. 2013. Hydrologic impact of regional climate change for the snowfed and glacierfed river basins in the Republic of Tajikistan: hydrological response of flow to climate change. Hydrological Processes 27: 4057-4070. DOI:10.1002/ hyp. 9535.

López-Moreno J, García-Ruiz JM. 2004. Influence of snow accumulation and snowmelt on streamflow in the central Spanish Pyrenees/Influence 
de l'accumulation et de la fonte de la neige sur les écoulements dans les Pyrénées centrales espagnoles. Hydrological Sciences Journal 49: 787-802.

Li ZL, Shao QX, Xu ZX, Cai XT. 2010a. Analysis of parameter uncertainty in semi-distributed hydrological models using bootstrap method: a case study of SWAT model applied to Yingluoxia watershed in northwest China. Journal of Hydrology 385: 76-83. DOI:10.1016/j. jhydrol.2010.01.025.

Li ZQ, Wang WB, Zhang MJ, Wang FT, Li HL. 2010b. Observed changes in streamflow at the headwaters of the Urumqi River, eastern Tianshan, central Asia. Hydrological Processes 24: 217-224. DOI:10.1002/ hyp.7431.

Liu C, Han T. 1991. Relation between recent glacier variations and climate in the Tien Shan mountains, central Asia. Annals of Glaciology 16: $11-16$.

Liu SY, Sun WX, Shen YP. 2003. Glacier change since the little ice age maximum in the western Qilian mountains, northwest China. Journal of Glaciological 49(164): 117-124.

Liu SY, Yao XJ, Guo WQ, Xu JL, Shangguan DH, Wei JF, Bao WJ, Wu LZ. 2015. The contemporary glaciers in China based on the second Chinese glacier inventory. Acta Geographica Sinica 70(1): 3-16 (in Chinese).

Liu ZF, Xu ZX, Huang JX, Charles SP, Fu GB. 2010. Impacts of climate change on hydrological processes in the headwater catchment of the Tarim River basin, China. Hydrological Processes 24: 196-208. DOI:10.1002/Hyp.7493.

Luo Y, Arnold J, Allen P, Chen X, Gelfan A. 2012. Baseflow simulation using SWAT model in an inland river basin in Tianshan Mountains, Northwest China. Hydrology and Earth System Sciences 16: 1259-1267. DOI:10.5194/hess-16-1259-2012.

Luo Y, Arnold J, Liu SY, Wang XY, Chen X. 2013. Inclusion of glacier processes for distributed hydrological modeling at basin scale with application to a watershed in Tianshan Mountains, northwest China. Journal of Hydrology 477: 72-85. DOI:10.1016/j.jhydrol.2012.11.005.

Lutz AF, Immerzeel WW, Gobiet A, Pellicciotti F, Bierkens MFP. 2013. Comparison of climate change signals in CMIP3 and CMIP5 multimodel ensembles and implications for Central Asian glaciers. Hydrology and Earth System Sciences 17: 3661-3677. DOI:10.5194/ hess-17-3661-2013.

Lutz AF, Immerzeel WW, Shrestha AB, Bierkens MFP. 2014. Consistent increase in High Asia's runoff due to increasing glacier melt and precipitation. Nature Climate Change 4: 587-592. DOI:10.1038/ nclimate 2237.

Madsen H, Lawrence D, Lang M, Martinkova M, Kjeldsen TR. 2014. Review of trend analysis and climate change projections of extreme precipitation and floods in Europe. Journal of Hydrology 519: 3634-3650. DOI:10.1016/j.jhydrol.2014.11.003.

Marzeion B, Jarosch AH, Gregory JM. 2014. Feedbacks and mechanisms affecting the global sensitivity of glaciers to climate change. The Cryosphere 8: 59-71. DOI:10.5194/Tc-8-59-2014.

Marzeion B, Jarosch AH, Hofer M. 2012. Past and future sea-level change from the surface mass balance of glaciers. The Cryosphere 6 : 1295-1322. DOI:10.5194/tc-6-1295-2012.

McBean E, Motiee H. 2008. Assessment of impact of climate change on water resources: a long term analysis of the Great Lakes of North America. Hydrology and Earth System Sciences 12: 239-255.

Miller JD, Immerzeel WW, Rees G. 2012. Climate change impacts on glacier hydrology and river discharge in the Hindu Kush-Himalayas a synthesis of the scientific basis. Mountain Research and Development 32: 461-467. DOI:10.1659/Mrd-Journal-D-12-00027.1.

Monk WA, Peters DL, Curry RA, Baird DJ. 2011. Quantifying trends in indicator hydroecological variables for regime-based groups of Canadian rivers. Hydrological Processes 25: 3086-3100. DOI:10.1002/Hyp.8137.

Moran-Tejeda E, Lorenzo-Lacruz J, Lopez-Moreno JI, Rahman K, Beniston M. 2014. Streamflow timing of mountain rivers in Spain: recent changes and future projections. Journal of Hydrology 517: 1114-1127. DOI:10.1016/j.jhydrol.2014.06.053.

Moriasi D, Arnold J, Van Liew M, Bingner R, Harmel R, Veith T. 2007. Model evaluation guidelines for systematic quantification of accuracy in watershed simulations. Transactions of the ASABE 50: 885-900.

Nalley D, Adamowski J, Khalil B. 2012. Using discrete wavelet transforms to analyze trends in streamflow and precipitation in Quebec and Ontario (1954-2008). Journal of Hydrology 475: 204-228. DOI:10.1016/j.jhydrol.2012.09.049.

Narama C, Kääb A, Duishonakunov M, Abdrakhmatov K. 2010. Spatial variability of recent glacier area changes in the Tien Shan Mountains, Central Asia, using Corona ( 1970), Landsat ( 2000), and ALOS ( 2007) satellite data. Global and Planetary Change 71: 42-54. DOI:10.1016/j.gloplacha.2009.08.002.

Neitsch SL, Arnold JG, Kiniry JR, Williams JR. 2011. Soil and Water Assessment Tool Theoretical Documentation, Version 2009.

Osmonov A, Bolch T, Xi C, Kurban A, Guo W. 2013. Glacier characteristics and changes in the Sary-Jaz River Basin (Central Tien Shan, Kyrgyzstan) - 1990-2010. Remote Sensing Letters 4: 725-734. DOI:10.1080/2150704x.2013.789146.

Pandey P, Venkataraman G. 2013. Changes in the glaciers of ChandraBhaga basin, Himachal Himalaya, India, between 1980 and 2010 measured using remote sensing. International Journal of Remote Sensing 34: 5584-5597. DOI:10.1080/01431161.2013.793464.

Parry ML. 2007. Climate Change 2007: impacts, adaptation and vulnerability: contribution of Working Group II to the fourth assessment report of the Intergovernmental Panel on Climate Change. Cambridge University Press, Cambridge.

Pellicciotti F, Carenzo M, Bordoy R, Stoffel M. 2014. Changes in glaciers in the Swiss Alps and impact on basin hydrology: current state of the art and future research. Science of the Total Environment 493: 1152-1170. DOI:10.1016/j.scitotenv.2014.04.022.

Radic V, Hock R. 2014. Glaciers in the Earth's hydrological cycle: assessments of glacier mass and runoff changes on global and regional scales. Surveys in Geophysics 35: 813-837. DOI:10.1007/s10712-0139262-y.

Savitskiy AG, Schlüter M, Taryannikova RV, Agaltseva NA, Chub VE. 2008. Current and future impacts of climate change on river runoff in the Central Asian river basins. In Adaptive and integrated water management. Springer: Berlin; 323-339.

Sen PK. 1968. Estimates of the regression coefficient based on Kendall's tau. Journal of the American Statistical Association 63: 1379-1389.

Shangguan D, Liu S, Ding Y, Ding L, Xu J, Jing L. 2009. Glacier changes during the last forty years in the Tarim Interior River basin, northwest China. Progress in Natural Science 19: 727-732. DOI:10.1016/j. pnsc.2008.11.002

Singh P, Ramasastri KS, Kumar N, Arora M. 2000. Correlations between discharge and meteorological parameters and runoff forecasting from a highly glacierized Himalayan basin. Hydrological Sciences Journal 45: 637-652. DOI:10.1080/02626660009492368.

Solomina O, Barry R, Bodnya M. 2004. The retreat of Tien Shan glaciers (Kyrgyzstan) since the Little Ice Age estimated from aerial photographs, lichenometric and historical data. Geografiska Annaler: Series A, Physical Geography 86: 205-215.

Solomon S. 2007. Climate change 2007 - the physical science basis: Working group I contribution to the fourth assessment report of the IPCC. Cambridge University Press, Cambridge.

Sorg A, Bolch T, Stoffel M, Solomina O, Beniston M. 2012. Climate change impacts on glaciers and runoff in Tien Shan (Central Asia). Nature Climate Change 2: 725-731.

Sorg A, Huss M, Rohrer M, Stoffel M. 2014. The days of plenty might soon be over in glacierized Central Asian catchments. Environmental Research Letters 9: . DOI:10.1088/1748-9326/9/10/104018.

Stahl K, Moore RD, Shea JM, Hutchinson D, Cannon AJ. 2008. Coupled modelling of glacier and streamflow response to future climate scenarios. Water Resources Research 44: W02422. DOI: 10.1029/ 2007wr005956.

Tao B, Tian HQ, Ren W, Yang J, Yang QC, He RY, Cai WJ, Lohrenz S. 2014. Increasing Mississippi river discharge throughout the $21 \mathrm{st}$ century influenced by changes in climate, land use, and atmospheric $\mathrm{CO}_{2}$. Geophysical Research Letters 41: 4978-4986. DOI:10.1002/ 2014g1060361.

Unger-Shayesteh K, Vorogushyn S, Farinotti D, Gafurov A, Duethmann D, Mandychev A, Merz B. 2013. What do we know about past changes in the water cycle of Central Asian headwaters? A review. Global and Planetary Change 110: 4-25.

Wang HJ, Chen YN, Li WH, Deng HJ. 2013. Runoff responses to climate change in arid region of northwestern China during 1960-2010. Chinese Geographical Science 23: 286-300. DOI:10.1007/s11769-013-0605-x. 
Wang SF, Kang SZ, Zhang L, Li FS. 2008. Modelling hydrological response to different land-use and climate change scenarios in the Zamu River basin of northwest China. Hydrological Processes 22: 2502-2510. DOI:10.1002/hyp.6846.

Wang Y, Hou S, Liu Y. 2010. Glacier changes in the Karlik Shan, eastern Tien Shan, during 1971/72-2001/02. Annals of Glaciology 50: 39-45. DOI:10.3189/172756410790595877.

Wang ZG, Ficklin DL, Zhang YY, Zhang MH. 2012. Impact of climate change on streamflow in the arid Shiyang River Basin of northwest China. Hydrological Processes 26: 2733-2744. DOI:10.1002/hyp.8378.

Wortmann M, Krysanova V, Kundzewicz ZW, Su B, Li X. 2014. Assessing the influence of the Merzbacher Lake outburst floods on discharge using the hydrological model SWIM in the Aksu headwaters, Kyrgyzstan/NW China. Hydrological Processes 28: 6337-6350. DOI:10.1002/Hyp.10118.

Xu CC, Chen YN, Chen YP, Zhao RF, Ding H. 2013a. Responses of surface runoff to climate change and human activities in the arid region of central Asia: a case study in the Tarim river basin, China. Environmental Management 51: 926-938. DOI:10.1007/s00267-013-0018-8.

$\mathrm{Xu} \mathrm{JH}$, Chen YN, Li WH, Nie Q, Hong YL, Yang Y. 2013b. The nonlinear hydro-climatic process in the Yarkand River, northwestern China. Stochastic Environmental Research and Risk Assessment 27: 389-399. DOI:10.1007/s00477-012-0606-9.

Yasutomi N, Hamada A, Yatagai A. 2011. Development of a long-term daily gridded temperature dataset and its application to rain/snow discrimination of daily precipitation. Global Environmental Research V15N2: 165-172.

Yatagai A, Kamiguchi K, Arakawa O, Hamada A, Yasutomi N, Kitoh A. 2012. APHRODITE: constructing a long-term daily gridded precipitation dataset for Asia based on a dense network of rain gauges. Bulletin of the American Meteorological Society 93: 1401-1415. DOI:10.1175/ bams-d-11-00122.1.

Yucel I, Guventurk A, Sen OL. 2015. Climate change impacts on snowmelt runoff for mountainous transboundary basins in eastern Turkey. International Journal of Climatology 35: 215-228. DOI: $10.1002 /$ Joc.3974.

Zang CF, Liu J, van der Velde M, Kraxner F. 2012. Assessment of spatial and temporal patterns of green and blue water flows under natural conditions in inland river basins in Northwest China. Hydrology and Earth System Sciences 16: 2859-2870. DOI:10.5194/hess-16-28592012.

Zhang S, Ye B, Liu S, Zhang X, Hagemann S. 2012. A modified monthly degree-day model for evaluating glacier runoff changes in China. Part I: model development. Hydrological Processes 26: 1686-1696. DOI:10.1002/hyp.8286.

Zhao QD, Ye BS, Ding YJ, Zhang SQ, Yi SH, Wang J, Shangguan DH, Zhao CC, Han HD. 2013. Coupling a glacier melt model to the Variable Infiltration Capacity (VIC) model for hydrological modeling in northwestern China. Environmental Earth Sciences 68: 87-101. DOI:10.1007/s12665-012-1718-8. 